\title{
Marin Sorescu - secvențe de interviu
}

\author{
Drd. ANDONIE (ARDEAN) Raluca \\ Universitatea „Dunărea de Jos” din Galați
}

\begin{abstract}
In front of a reporter, most interviewees wear masks, each assuming a prepainted role, emphasizing consciously the exact feature that most readers want to know about the author or about the subject. Marin Sorescu, the complete author who was remarked both in the country and beyond its borders, was not afraid to reveal himself to those who wanted to portray him in interviews throughout his lifetime. The sincerity, the depth of ideas, and the originality of the way in which he understood the true nature of things, are elements easy to be noticed within the materials signed by journalists who dared to penetrate into the Sorescian universe. The author confesses that he finds particular satisfaction in discovering new talents to present to the audience without fear or even with the slightest thought that by this approach he could neglect his own potential. Further than promoting the authors whom he considered talented, Marin Sorescu, was one of the few promoters of Romanian cultural values abroad, persisting on promoting the culture by all means, therefore, becoming a cultural diplomatic passport worldwide.
\end{abstract}

Keywords: interview, self, cultural passport, originality

Unul dintre cei mai cunoscuți scriitori britanici, David Lodge, declara într-un interviu, că scriitorul este o altă persoană în spatele cărții, cititorii putând deseori fi deziluzionați in momentul unei întâlniri față în față.

Plecând de la acest aspect dar și de la cea mai simplă definiție a interviului, care se releva ca specia care informează și elucidează prin intermediul unui dialog, specie care a ajuns să cunoască în publicistica românească un loc de primă însemnătate, vom încerca să scoatem în relief portretul lui Marin Sorescu, felul în care acesta se deschide în comunicarea cu publicul larg, prin intermediul interviurilor acordate.

Este cunoscut faptul că acest prolific scriitor și om de cultură a intervievat la rândul său o serie de personalități marcante din cultura românească, ipostază în care s-a dovedit a fi un fin psiholog și bun cunoscător al firii omenești. 
Interviurile sunt nu numai depozite de informație inedită, mijloace de vehiculare a unor idei și experiențe, dar și-au cucerit unele calități literare prin evidențierea unor profiluri bine individualizate.

Volumul V închinat operelor lui Marin Sorescu, volum apărut sub efigia Academiei Române și sub atenta coordonare a celui care poate 1-a cunoscut cel mai bine pe Marin Sorescu - acad. Eugen Simion - adună în filele sale partea de publicistică a lui "Sorescu Mondialul" - mărturisiri și interviuri.

In interviul luat de Nicolae Florescu și intitulat "/Nu numai poetul se poate defini greu, ci oricare om", chiar din debutul acestuia Marin Sorescu ni se înfățișează ca un om deschis, conștient de propria valoare și destul de dezamăgit că, deși s-a arătat deschis la dialogul cu publicul cititor, atât acesta cât și criticii vremii nu l-au deslușit încă în întregime.

"Tocmai intenționam să nu mai dau interviuri. Ai văzut că sunt destul de multe. M-am lăsat descusut... și n-am spus nimic. Nu e bine să se știe chiar tot ce ai pe inimă; ca literatură - căci atunci nu mai prezinți în fața ta nici un mister. Incepi să citești prin reviste cam cine ești și cu ce te ocupi. Asta e plictisitor: să afli mereu că ești scriitor, după cum însuți ai mărturisit-o nu știu cui."119

Tot în cadrul aceluiași interviu apare și fireasca întrebare "cine sunteți, Marin Sorescu? - întrebare prin care se interlocutorul lui Marin Sorescu insistă ca acesta să se dezvăluie, să iasă din "carapacea" pe care a perceput-o în primul răspuns. Scriitorul răspunde în stilu-i caracteristic, cu un umor în spatele căruia se ascund atât o mare modestie dar și o mare dezamăgire că, deși s-a autodefinit atât prin operele sale cât și prin calitățile pe care le-a dezvăluit ca om de cultură, traducător și purtător de stindard al culturii românești peste hotare, publicul încă nu îl poate identifica cu toate acestea.

"Mă tot întreb și eu, la sugestia dumitale și a altora, și nu reușesc să dau peste un răspuns care să-mi placă. Sau să nu-mi placă, dar să fie exact,să fie un răspuns, cât de cât." ${ }^{\prime 120}[. .$.

"Pe scurt, habar n-am cine sunt. Cine află primul să-mi spună și mie. Îmi vine să râd atunci când criticii dau impresia că știu totul despre mine citindu-mi una sau

\footnotetext{
119 Marin Sorescu, Opere, vol. V Publicistică, Editura Fundației Naționale pentru Știință și Artă, București 2005, p. 968

2 Lawrence Grobel, Arta interviului - lecții de la un "maestru al meseriei", Editura Publica, 2016

${ }^{120}$ Marin Sorescu, Opere, vol. V Publicistică, Editura Fundației Naționale pentru Știință și Artă, București 2005, p. 968
} 
alta din cărți, pe sărite. Nu numai poetul se poate defini greu, ci oricare om. Numai că pe cei mai mulți nu-i întreabă nimeni."121

Un alt răspuns care ni-1 relevă pe Marin Sorescu ca pe un om foarte deschis, modest, deși conștient de propria valoare este cel din interviul intitulat "Nu mi-am propus să devin un om popular" consemnat de Vladimir Brânduș. Întrebat care crede că este cel mai valoros element prin care scriitorul consideră că se poate integra în contemporaneitate și pe care dorește să-l transmită conștiinței epocii în care trăim, Sorescu revine asupra faptului că adevărata valoare a unui om este modul în care își exprimă interiorul, felul în care sufletul său își conturează experiențele vieții, experiențe pe care le percepe la fel ca ale celorlalți oameni, simțind astfel că nu se deosebește de ei decât prin faptul că a avut curajul și puterea de a așterne aceste experiențe pe hârtie.

"Nu știu dacă acesta este elementul cel mai valoros, dar dorința mea e să scriu cât mai exact despre mine însumi, știind că dacă nu mă trădez pe mine, în același timp mă simt foarte apropiat de cititori. Nu vreau să mă consider o excepție. Adică să scriu ca un om obișnuit, ca și cum ar scrie un om de pe stradă despre viața lui și pe care citindu$l$, ceilalți se recunosc." 122

George Pruteanu în ale sale referințe critice despre Marin Sorescu, intitulate sugestiv "Marin Sorescu, deocamdată", consemna că "poezia lui Marin Sorescu a adus, la epoca apariției ei, o senzație de destindere, și prospețime. Era o manieră de o candoare tristă și de o gravitate șugubeață de a privi lumea."

Indiferent de întrebările, malițioase sau nu, apărute în interviurile susținute, Marin Sorescu a rămas același oltean pragmatic, cu picioarele pe pământ, care nu se dezminte de principiile sănătoase în care a crescut și a trăit.

Ion Marin Almăjan, într-un interviu luat la Timișoara și intitulat "Poet sau dramaturg, eseist sau critic, întotdeauna un cetățean" îl provoacă pe Marin Sorescu să răspundă afirmațiilor făcute de unii confrați ai poetului, care erau convinși că acesta a căutat un refugiu în teatru datorită faptului că filonul său poetic s-ar fi epuizat.

Încă o dată, așa cum începem să-l cunoaștem pe Sorescu, aflăm că acesta spune despre sine că are o construcție psihică ce nu-i permite să își piardă identitatea în fața unor ropote de aplauze și aprecieri. Își definește pasiunea, scrisul, ca pe o "boală nevindecabilă" ${ }^{5}$ ce ar trebui să vină odată cu nașterea, iar

${ }^{121}$ Marin Sorescu, Opere, vol. V Publicistică, Editura Fundației Naționale pentru Știință și Artă, București 2005, p.969

122 Marin Sorescu, Opere, vol. V Publicistică, Editura Fundației Naționale pentru Știință și Artă, București 2005, p. 952 
critica laudativă, aplauzele sau elogiile sunt considerate a fi neprincipiale. Practic, Sorescu, își definește talentul și condiția de artist, ca pe un dat pe care trebuie să îl respecte, să îl protejeze și să îl fructifice în izolare. Declară presei că decizia de a scrie teatru vine ca o completare a "filonului poetic". "Cred că poetul trebuie să fie un scriitor complex, îmbinând metode de creație, care este inspirația în cazul poeziei, cu observația în cazul teatrului și cu spiritul critic atunci când pune mâna să scrie eseuri. Dar mai presus de orice atât poetul cât și dramaturgul este un cetățean, un om al timpului său, un exponent al poporului său."123

$\mathrm{Cu}$ toate că de cele mai multe ori universul sorescian este perceput ca o realitate concret-cerebrală și o foame devoratoare de spațiu, limbajul lui Sorescu, la fel ca în interviuri, este accesibil ca formulare, lucid, sceptic, cu voință și putere de acțiune.

Descoperim la Sorescu, prin intermediul acestor interviuri, o robustețe psihică ce-și trage seva din rădăcinile rămase în satul copilăriei, aceeași spontaneitate care-i caracterizează întreaga operă, dar și vivacitatea comunicării, optimismul și siguranța pe care o degajă atât omul cât și opera. Astfel, Sorescu este un cumul de stări și de emoții pe care nu le observi decât la o mai atentă privire. De altfel, tot Sorescu ne atrage atenția asupra acestui fapt în interviul realizat cu ocazia decernării Premiilor Uniunii Scriitorilor din anul 1965:

"Fiecare carte este un loc pentru stări de spirit, care sunt ireversibile ca și timpul. Dacă ești atent vei observa că nu trăiești de două ori aceeași emoție (după cum poți și să nu o trăiești niciodată). Nu există pericolul repetării. Nu mi-am ales deliberat forma versurilor mele. A venit singură."124

Interviul luat la Târgu-Mureș în februarie 1984, aduce în atenție o altă fațetă a diamantului Sorescu : bucuria creației. Întrebat fiind care e sentimentul dominat care-l însoțește la masa de lucru, acesta răspunde:

"Un sentiment de bucurie. Chiar dacă scriu tragedii, descătușându-mă de pasiunea unor trăiri, mă umplu de bucurie, această bucurie vine, evident, greu și masa de lucru e o scenă la care te condamni singur să tai dintr-o inexplicabilă nevoie de bucurii. Cititorii văd uneori numai partea relaxantă, zâmbetul mușchilor scrisului, nu și încordarea tăierii în munte." 125

${ }^{123}$ Marin Sorescu, Opere, vol. V Publicistică, Editura Fundației Naționale pentru Știință și Artă, București 2005, p. 875

${ }_{124}$ Marin Sorescu, Opere, vol. V Publicistică, Editura Fundației Naționale pentru Știință și Artă, București 2005, p. 875

${ }^{125}$ http://www.poezie.ro/index.php/article/165756/Interviu cu Marin Sorescu 
Pe de altă parte, Maria Luiza Cristescu în "Poeții despre ei înșiși și despre poezia contemporană" consemnează părerea lui Sorescu despre critica literară a vremii în opoziție cu truda scriitorului: "Critica te încurajează atâta timp cât nu e sigură pe tine. Când vede într-adevăr că ești "talentat" i se încleștează fălcile. Ți se pune în față o barieră și trebuie să aștepți plutonul din urmă. Asta distruge orice avânt."126[...]; "În ceea ce privește greșelile greșiților mei. Ele constau în faptul că m-au apreciat pentru lucruri care nu sunt esențiale și m-au înjurat pentru lucruri pe care nu le-au înțeles. [...]Dar ce încredere oarbă mai poți avea în judecata estetică a unui om care citește Iliada și înțelege Odiseea?"127

Cuvintele sunt de prisos. Sorescu a surprins prin aceste cuvinte marea sa deziluzie cu privire la modul în care formatorii de opinie precum criticii literari nu acordă suficientă atenție conținutului, ei reținând mai ales forma unei lucrări.

Luciditatea caracteristică lui Sorescu transpare în convorbirea consemnată de Daniela și Ștefan Melancu în cadrul revistei Echinox - revista de cultură a studenților de la Universitatea Babeș-Bolyai din Cluj, cu ocazia comemorării poetului, o republicare a interviului apărut în numărul 4 al revistei din anul 1983, interviu realizat la Colocviul național de literatură "M. Eminescu" de la Iași, unde Sorescu era invitat. Întrebat de către reporter dacă este cu putință ca marii artiști să devină "zei"11 apreciați abia după trecerea în neființă, Marin Sorescu răspunde ferm că autorii nu sunt zei nici înainte, nici după trecerea în neființă, însă completează laconic " de obicei, se așteaptă dispariția autorului cu un sentiment de ușurare pentru a se face ordine în oprea lui, deși această ordine se poate face și în timpul vieții. În cadrul aceluiași interviu, marele autor își exprimă regretul față de felul în care este perceput și valorificat atât de marele public dar și de cei din breasla sa "În alte țări, poeți de vârsta mea, de circulația mea, au un statut cu totul deosebit. Asta nu înseamnă că cer ceva, nu vreau decât să pot fi lăsat în pace să scriu ce am de scris."11

În 1981, într-un interviu din România literară, Marin Sorescu era întrebat: „Care a fost faptul sau întâmplarea extraordinară pe care ați trăit-o până acum?” Răspunsul: „Faptul de a te fi născut este o întâmplare extraordinară. Eu nu-mi revin din această întâmplare nici acum". 128

\footnotetext{
${ }^{126}$ Marin Sorescu, Opere, vol. V Publicistică, Editura Fundației Naționale pentru Știință și Artă, București 2005, p. 878

127 Ibidem

128 https://yorick.ro/marin-sorescu-faptul-de-a-te-fi-nascut-este-o-intamplareextraordinara-eu-nu-mi-revin-din-aceasta-intamplare-nici-acum/
} 
Poate cel care a surprins cel mai bine multiplele fațete ale lui Sorescu, dar și drama sa scriitoricească a fost academicianul Eugen Simion.

Anul acesta, pe 28 februarie 2018, Muzeul Literaturii Române a găzduit o comemorare a poetului, ocazie cu care academicianul Eugen Simion a făcut o serie de afirmații juste despre sensibilul Sorescu, "scriitorul cu inepuizabile resurse de farmec și o frapantă originalitate". Academicianul este de părere că ironia nu l-a protejat pe Sorescu de presa românească ci dimpotrivă l-a expus, ajungând să fie contestat atât de autorii care au fost ajutați de președintele Uniunii Scriitorilor să se lanseze și i-a sprijinit în demersul lor cultural, dar și de alții. Eugen Simion este de părere că după trecerea sa în neființă, Marin Sorescu a reușit să își învingă atât dușmanii cât și adversarii, prin calitatea și acuratețea operei sale, recunoscută la nivel internațional "Un poet irlandez care a luat Premiul Nobel a fost prefațat de Sorescu. Nu e lucru puțin, era tradus peste tot."11 Autorul este de părere că tocmai această recunoaștere internațională a lui Sorescu i-a adus dușmănia compatrioților săi. Atunci când face referire la textele din zona de dramaturgie semnată de Sorescu, Eugen Simion spune că nici măcar o virgulă nu s-a învechit în piesa "Paracliserul" și este de părere că aceasta este "o creație dramatică extraordinară"11.

Ce-ar mai fi de spus după această prezentare? Poate doar că Sorescu a fost egal cu sine însuși atât în viață cât și în operă, că în oricare postură - de scriitor sau intervievat - a dat aceeași valoare cuvintelor și și-a exprimat la fel de pregnant rădăcinile sale oltenești, rădăcini care l-au alimentat de-a lungul anilor cu pragmatismul locurilor natale, cu luciditatea celui care își cunoaște propria valoare și care, indiferent de părerile celor din jur, nu s-a dezis de sine însuși pentru a merge cu valul.

\section{BIBLIOGRAFIE:}

Antofi, Simona, Despre absurd și rescriere postmodernă, Communication Interculturelle et Littérature, Nr. 1/2016, vol.I, pp. 50-54, ISSN 1844-6965, Ed.Casa Cartii de Stiintă, Cluj.

Cenac Oana, Discurs ideologic în "Ateneu" 1965, Actele conferinţei internaţionale Lexic comun / Lexic specializat. Democratizarea cunoașterii" sau migrația lexicului specializat spre lexicul comun, ediția a X-a, Universitatea „Dunărea de Jos” din Galați, Facultatea de Litere, Centrul de Cercetare Comunicare interculturală și 
literatură, 19 - 20 mai 2017, publicată în Analele Universității „Dunărea de Jos” din Galați, Fascicula XXIV Lexic comun / lexic specializat, revistă indexată in bazele de date internaționale EBSCO: https://www.ebscohost.com/titleLists/cmscoverage.pdf, MLA (Modern Language Association, New York, www.mla.org) MLA International Bibliography \& Directory of Periodicals, CEEOL și Fabula. La recherche en littérature (www.fabula.org), anul X, nr. 2(18) /2017, Editura Casa Cărții de Ştiinţă, Cluj-Napoca, 2017, ISSN 1844-9476, p. 31-48.

Cenac, Oana, (2014). Aspects of Popular Stylistic Language in the Work of Ion Creang $\breve{a}$ in Proceedings of the International Conference of Common Vocabulary/Specialized Vocabulary: Manifestations of Creativity of Human Language, 6-7 of June, 2014, p. 178 - 186, WOS: 000378446400018, citat în Nicoleta Hristu Hurmuzache, IDENTITATEA MALADIVĂ ÎN ROMANUL LUI MAX BLECHER, în volumul Spații culturale deschise. Latinitate și romanitate, Casa cărții de știință, Cluj-Napoca, 2016, ISBN 978-606-17-1081-2, WOS: 000378446400018 Grobel, Lawrence, Arta interviului - lecții de la un "maestru al meseriei", Editura Publica, 2016.

Ifrim, Nicoleta Constructing and De-constructing Cultural Identity in the Contemporary European Paradigm - The Romanian Example and its Eurocentric Dilemmas, în Procedia-Social and Behavioral Journal (ISSN: 1877-0428) (ISSN: 18770509),vol.63/2012, pp. 29-34, DOI 10.1016/j.sbspro.2012.10.006, http://www.sciencedirect.com/science/journal/18770428/63/supp/C, WOS:000361477200005

Miu, Constantin Publicistica lui Marin Sorescu, Editura Cellina, Craiova, 2006 Sorescu, Marin, Opere, vol. V Publicistică, Editura Fundației Naționale pentru Știință și Artă, București 2005

\section{Webografie:}

http://www.poezie.ro/index.php/article/165756/Interviu cu Marin Sorescu http://ziarullumina.ro/perspective-marin-sorescu-inepuizabile-resurse-defarmec-131795.html http://revistaechinox.ro/2016/02/vintage-interviu-marin-sorescu-1983/ https://yorick.ro/marin-sorescu-faptul-de-a-te-fi-nascut-este-o-intamplareextraordinara-eu-nu-mi-revin-din-aceasta-intamplare-nici-acum/ 